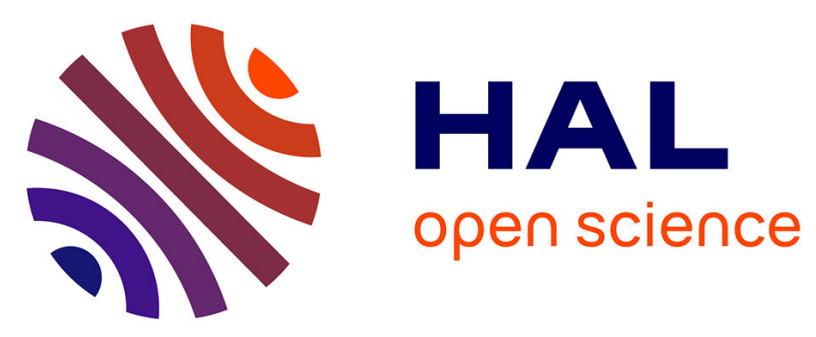

\title{
Long-range transport of continentally-derived particulate carbon in the marine atmosphere: evidence from stable carbon isotope studies
}

Hélène Cachier, Patrick Buat-Ménard, Michel Fontugne, Roger Chesselet

\section{To cite this version:}

Hélène Cachier, Patrick Buat-Ménard, Michel Fontugne, Roger Chesselet. Long-range transport of continentally-derived particulate carbon in the marine atmosphere: evidence from stable carbon isotope studies. Tellus B - Chemical and Physical Meteorology, 1986, 38 (3-4), pp.161-177. 10.3402/tellusb.v38i3-4.15125 . hal-03540449

\author{
HAL Id: hal-03540449 \\ https://hal.science/hal-03540449
}

Submitted on 24 Jan 2022

HAL is a multi-disciplinary open access archive for the deposit and dissemination of scientific research documents, whether they are published or not. The documents may come from teaching and research institutions in France or abroad, or from public or private research centers.
L'archive ouverte pluridisciplinaire HAL, est destinée au dépôt et à la diffusion de documents scientifiques de niveau recherche, publiés ou non, émanant des établissements d'enseignement et de recherche français ou étrangers, des laboratoires publics ou privés. 


\section{Long-range transport of continentally-derived particulate carbon in the marine atmosphere: evidence from stable carbon isotope studies}

\section{Hélène Cachier, Patrick Buat-Ménard, Michel Fontugne \& Roger Chesselet}

To cite this article: Hélène Cachier, Patrick Buat-Ménard, Michel Fontugne \& Roger Chesselet (1986) Long-range transport of continentally-derived particulate carbon in the marine atmosphere: evidence from stable carbon isotope studies, Tellus B: Chemical and Physical Meteorology, 38:3-4, 161-177, DOI: 10.3402/tellusb.v38i3-4.15125

To link to this article: https://doi.org/10.3402/tellusb.v38i3-4.15125

\section{(c) 1986 The Author(s). Published by Taylor \& Francis.}

曲 Published online: 18 Jan 2017.

Submit your article to this journal 지

Џ Article views: 111

Q View related articles $₫$

7 Citing articles: 2 View citing articles 준 


\title{
Long-range transport of continentally-derived particulate carbon in the marine atmosphere: evidence from stable carbon isotope studies
}

\author{
By HÉLÈNE CACHIER, PATRICK BUAT-MÉNARD, MICHEL FONTUGNE and \\ ROGER CHESSELET, Centre des Faibles Radioactivités, Laboratoire mixte CNRS-CEA, \\ BP I, avenue de la Terrasse, 91190 Gif-sur Yvette, France
}

(Manuscript received March 10; in final form April 14, 1986)

\begin{abstract}
Since 1979, we have investigated marine and non-marine sources of particulate carbon in the marine atmosphere from measurements of carbon concentration and isotopic composition $\left({ }^{13} \mathrm{C} /{ }^{12} \mathrm{C}\right)$. Aerosol samples were collected, mostly during the Sea/Air Exchange (SEAREX) Program experiments, in the northern and southern hemispheres (Sargasso Sea, Enewetak Atoll, Peru upwelling, American Samoa, New Zealand, Amsterdam Island). The concentration and the isotopic composition of particulate carbon of marine origin are about the same in both hemispheres $\left(C_{\text {mean }}=0.07 \mu \mathrm{gC} \mathrm{m}-3, \delta^{13} C_{\text {mean }}=-21 \%\right.$ ). This component is primarily associated with large sea-salt particles (diameter $>3 \mu \mathrm{m}$ ). Particulate carbon of continental origin displays a variable isotopic composition $\left(\delta^{13} \mathrm{C}\right.$ range : -23 to $-28 \%$ ) and is primarily found attached to the smallest aerosol particles (diameter $<1 \mu \mathrm{m}$ ). This continental component shows little temporal variability, but its concentration is much lower in the southern hemisphere $\left(0.06 \mu \mathrm{gC} \mathrm{m}{ }^{-3}\right)$ than in the northern hemisphere $\left(0.45 \mu \mathrm{gC} \mathrm{m}^{-3}\right)$. Also, the northern hemisphere samples appear strongly depleted in ${ }^{13} \mathrm{C}$ compared to those from the southern hemisphere. This can be explained on the basis of our isotopic data over various continental areas (Paris region, Ivory Coast, Congo) as due to the predominance in the northern hemisphere of carbonaceous aerosols of anthropogenic origin derived either from industrial combustion processes or from biomass burning. On the other hand, our data set from the southern hemisphere appears to reflect primarily natural land-derived biogenic emissions.
\end{abstract}

\section{Introduction}

There is no doubt that carbonaceous aerosols generated over the continents undergo long-range atmospheric transport to remote oceanic areas. However, because of the paucity of data, the role of such long-range transport in the global atmospheric particulate (non-carbonate) carbon budget has not yet been assessed quantitatively (Duce, 1978; Duce et al., 1983). Indeed, up to now, quantitative information has been mostly restricted to soot and to specific organic compounds or classes of compounds which constitute only a minor fraction of total atmospheric particulate carbon (Simoneit et al., 1977;
Eichman et al., 1980; Daisey et al., 1981; Gagosian et al., 1982; Marty and Saliot, 1982; Andreae et al., 1984). Over the ocean, such an assessment requires first an evaluation of the relative contribution of marine versus continental sources of atmospheric particulate carbon. There is some evidence that a major fraction of the carbonaceous particles in the marine troposphere could be derived from continental sources, both natural and anthropogenic. This has been underlined by the fact that: (a) atmospheric particulate carbon concentrations are generally higher over land than over the oceans (Duce, 1978), (b) the concentrations in the marine atmosphere seem to be slightly lower in the 
southern than in the northern hemisphere (Cachier et al., 1983; Duce et al., 1983), and (c) a large fraction of atmospheric particulate carbon appears to be attached to particles with diameter smaller than $1 \mu \mathrm{m}$, whereas particulate carbon of direct marine origin would be essentially present on particles of much larger sizes, i.e., sea-salt aerosol droplets (Hoffman and Duce, 1977).

In this context, previous work in our laboratory (Chesselet et al., 1981) showed that the use of stable carbon isotope measurements $\left({ }^{13} \mathrm{C} /{ }^{12} \mathrm{C}\right)$ was a promising tool for estimating quantitatively the relative contributions of marine and nonmarine sources for the total particulate carbon in the marine troposphere. This work was based on the hypothesis that the differences in isotopic composition between marine and continental sources of carbonaceous matter (Sackett, 1964) could be found in their derived atmospheric particulate products. For a few atmospheric samples collected over the Tropical North Atlantic and Pacific, the isotopic composition of the particulate carbon was found to be close $\left(\delta^{13} C=-26 \pm 2 \%\right.$ ) to that inferred for atmospheric carbonaceous material of continental origin, based on measurements of aerosol samples collected in urban and semi-rural environments in France. Furthermore, analyses of 3 sizefractionated aerosol samples from the Tropical North Pacific indicated that the major mass of the carbonaceous aerosol was attached to particles with diameters smaller than $1 \mu \mathrm{m}$ in agreement with previous studies by Hoffman and Duce (1977). On the other hand, based on isotopic measurements of dissolved and particulate organic matter in surface seawaters of low and temperate latitudes, it has been suggested that particulate carbon in the larger size-fractions of the aerosol is likely to have a direct marine origin since its isotopic composition was close to that expected $\left(\delta^{13} C=-21 \pm 2 \%\right.$ ) for organic carbon associated with sea-salt droplets emitted to the marine atmosphere. These first data suggested too that no important isotopic fractionation was occurring during aerosol particle production and transport.

It has to be pointed out, however, that the extrapolation of such an approach on a global basis depends heavily on a careful consideration of the spatial and temporal variability of the isotopic signature of the marine and continental sources. Indeed, it has been shown that marine plankton collected in high-latitude regions is depleted in ${ }^{13} \mathrm{C}$ relative to plankton from lowand mid-latitudes (Fontugne and Duplessy, 1981). Furthermore, Cachier et al. (1985) have shown that over continental tropical regions, both the concentration and the isotopic composition of atmospheric particulate carbon exhibit a large temporal variability which reflects the diversity of the continental carbonaceous sources and their seasonal changes. These authors were able to define the isotopic characteristics of the various reservoirs identified as large scale sources of fine carbonaceous aerosols (i.e., natural emissions from the vegetation and biomass burning).

In this paper, we present data on the concentration and isotopic composition of the total (non-carbonate) atmospheric particulate carbon over various remote oceanic areas which cover a wide geographical distribution in the northern and the southern hemispheres. The relative contributions of the marine and the continental source fractions and their spatial and temporal variability are estimated. The observed interhemispheric variability of the concentration and isotopic composition of the atmospheric particulate carbon of continental origin is discussed from considerations of both the isotopic signature and the emission rate of the different continental source terms.

\section{Experimental}

\section{I. Sample collection}

The atmospheric particulate samples were obtained during various field experiments between 1979 and 1985 (Fig. 1). They were collected either from towers located on the windward shore of islands, or from bow towers on board research vessels. Sampling was carefully controlled by wind speed and direction in order to keep possible local contamination to a minimum (Chesselet et al., 1981; Peltzer et al., 1984; Buat-Menard and Duce, 1985).

Glass-fiber filters of various types and sizes (Whatman GF/C and GF/F, Gelman A/E) were used as collection substrates. Two types of samples were obtained, often simultaneously: (a) 


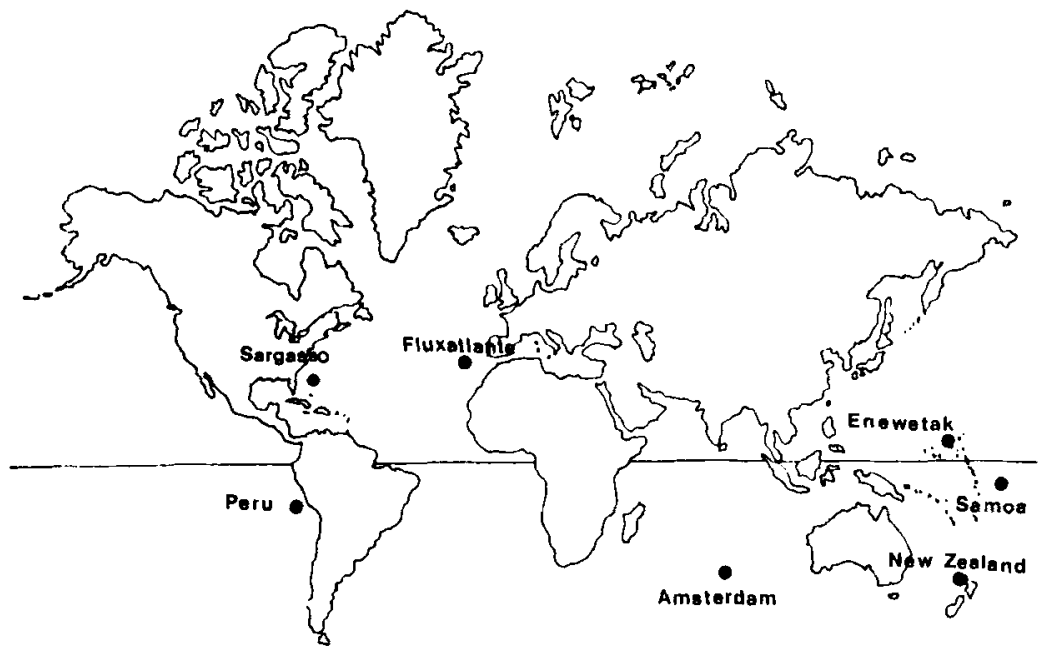

Fig. I. Location of atmospheric samples.

bulk aerosol samples collected by air-filtration (flow rate range: $15 \mathrm{~m}^{3} \mathrm{~h}^{-1}$ to $70 \mathrm{~m}^{3} \mathrm{~h}^{-1}$ ) and (b) size-separated aerosol samples collected with a Sierra model 235 high-volume 5-stage cascade impactor operating at $68 \mathrm{~m}^{3} \mathrm{~h}^{-1}$. Sampling duration was variable ( 2 days to 2 weeks) depending on the expected carbon concentration.

\subsection{Analytical procedures}

The collection surfaces were pre-cleaned in order to lower their organic carbon content. This operation is particularly critical for sampling at very remote locations. Dry combustion of the filters was used first for the Enewetak dry season samples (Chesselet et al., 1981). Since then, in order to reduce the variability of the blanks, the filters have been cleaned by solvent extraction in a soxhlet apparatus. The most satisfactory conditions for blank filter cleaning were found to be successive extractions over a 9-day period with different kinds of solvent (methanol, acetone, methylene chloride). Different batches of blank filters showed different carbon concentrations and isotopic compositions (from 1.8 to $0.04 \mu \mathrm{gC}$ $\mathrm{cm}^{-2}$ and from -22 to $-26 \%$ respectively) depending on the cleaning procedure adopted and on the filter type. However within a batch, the observed reproducibility of both the mass and the isotopic composition of the carbon present in the blanks was sufficient to enable measurements to be performed even with the lowest organic carbon concentrations found $\left(C \sim 2 \mu \mathrm{gC} \mathrm{cm} \mathrm{cm}^{-2}\right)$.
Prior to sampling, the filters were wrapped in aluminium foil also pre-cleaned with solvents. Filter samples were kept frozen in the foils until they were analyzed. Sample homogeneity was carefully checked by analyzing several aliquots. It was found to be good enough to allow analysis of fractions of the filters. For some samples, replicates were made after varying the time of storage (1 month to 3 years). No significant change in either the amount or the isotopic composition of the organic matter present was found.

Filters were decarbonated in hydrochloric acid fumes. The remaining carbon (referred to as particulate carbon) included organic carbon and any elemental carbon present on the substrate. It was then oxidized to $\mathrm{CO}_{2}$ by dry combustion at $1100^{\circ} \mathrm{C}$, purified and analysed for stable carbon isotopes using a VG Micromass $602 \mathrm{D}$ massspectrometer (Chesselet et al., 1981). Isotopic abundances are expressed relative to international standard PDB-1 as:

$\delta^{13} C=\left({ }^{13} C /{ }^{12} C_{\text {sample }} /{ }^{13} C /{ }^{12} C_{\text {standard }}-1\right) \times 1000$.

Concentrations were determined first by calibration of the intensity of the mass 44 peak of the mass-spectrometer; since 1984, a coulometric carbon analyser (Coulomat $702 \mathrm{C}$ Ströhleim) has been used. Determination of carbon concentration on separate aliquots by the two methods were in very good agreement and the observed 
differences were within the range of uncertainties inherent to each method.

Since most of the samples had small amounts of carbonaceous matter, blank corrections were required both for concentration and isotopic composition. The latter correction was made using the following equations:

$$
\begin{aligned}
& \left(\delta^{13} C \times C\right)_{\text {sample }}=\left(\delta^{13} C \times C\right)_{\text {blank }} \\
& \quad+\left(\delta^{13} C \times C\right)_{\text {aerosol }}, \\
& C_{\text {sample }}=C_{\text {blank }}+C_{\text {aerosol }} .
\end{aligned}
$$

Each analytical step contributed to the uncertainty of the results. The precision of the analysers (mass-spectrometer and carbon analyser) allowed concentration and ${ }^{13} \mathrm{C}$ determinations with uncertainties of the order of $1 \mu \mathrm{gC}$ and $0.01 \%$, respectively. The reproducibility of the isotopic composition using the dry combustion method has been tested with standard graphite aliquots and assessed to be in the range of 0.05 to $0.1 \%$ depending on the load of carbon (from $1000 \mu \mathrm{g}$ to $40 \mu \mathrm{g}$ ). The measurements of portions of filters have been necessitated by the volume limitation of the dry combustion method and to allow replication. It did not introduce any additional uncertainty in the isotopic determination, but was found to contribute significantly to the uncertainty in the mass of carbon ( 5 to $50 \mu \mathrm{g}$ for carbon range from 50 to $1000 \mu \mathrm{g}$ ). This could be due to the difficulty of evaluating precisely the area of the filter being used for analysis. The minimum size limitation for the representativeness of the aliquot has been found to be $\frac{1}{8}$ to $\frac{1}{4}$ of the sample and the minimum load of carbon required was $50 \mu \mathrm{g}$. The major part of the uncertainty was, however, most often due to the blank correction on the concentration and on the isotopic ratio of the samples, especially at very low concentrations. This correction depends on the nature of the filter and the cleaning procedure. Mean absolute errors for average aliquots of a filter have been estimated to be \pm 20 $\mu \mathrm{g}$ for the mass of carbon, and $\pm 0.5 \%$ for the isotopic composition, but the uncertainty on $\delta^{13} \mathrm{C}$ can be as high as $2 \%$ for filter samples having a very low carbon load (see Table 2).

\section{Results and discussion}

The analytical data are reported in Table 1 for bulk aerosol samples, and in Table 2 for cascade impactor samples. The concentrations given are blank corrected. They vary from 0.06 to $1.21 \mu \mathrm{gC}$ $\mathrm{m}^{-3}$. Other data available in the literature for concentration of the total organic carbon in aerosol samples from remote marine areas are reported in Table 3. They represent a good coverage of the two hemispheres and the agreement with our measurements, both for the mean value and the range is quite satisfactory. The small discrepancy between the 2 sets of data, apart from the question of representativeness of one or the other data set, can be easily explained by differences in analytical procedures. Some results from the literature are for the fine-size fraction of the aerosol only; others are for extractable organic matter (EOM) which ignores any refractory or elemental carbon though omnipresent in the marine atmosphere (Andreae et al., 1984; Heintzenberg, 1985). Over some marine regions, this could lead to a significant underestimate of the total carbonaceous aerosol concentration (Andreae, 1983); furthermore, the necessary conversion of EOM to total organic matter introduces another factor of uncertainty. The lowest concentrations ever reported are for our results from American Samoa. A few years before, Hoffman and Duce (1977) had conducted field experiments at the same location and found significantly higher concentrations. The observed differences for the two sets of data could be due to the more severe precautions taken against contamination in the present work, i.e., during the preparation of filters, the sampling and the processing of the samples.

The range of the isotopic composition of the bulk particulate carbon is -19.0 to $-28.3 \%$. There is a good agreement between the results obtained for bulk filters and those obtained for cascade impactor samples. The observed differences are generally within the range of the uncertainty on the determination of the isotopic composition.

\subsection{Variability of the carbonaceous aerosol over the ocean}

It appears from our data that the variability of the carbonaceous aerosol concentration over the ocean is more pronounced than previously thought (Duce et al., 1983). Moreover, as illustrated by Fig. 2, there is no doubt that the southern hemisphere concentrations are signifi- 
Table 1. Particulate carbon concentration and isotopic composition in air filter samples from remote oceanic areas

\begin{tabular}{|c|c|c|c|c|c|}
\hline Location & Mid-date & Vol $\left(\mathrm{m}^{3}\right)$ & $\left.C(\mu \mathrm{gC} \mathrm{m})^{-3}\right)^{*}$ & $\delta^{13} C(\%)$ & $\delta^{13} C_{\text {corr }}(\%$ \\
\hline \multicolumn{6}{|c|}{ Northern Hemisphere } \\
\hline BF 10 & Apr $/ 17$ & 8,500 & 0.88 & -25.6 & $-25.7 \pm 0.1$ \\
\hline BF 21 & $\mathrm{Apr} / 25$ & 7,600 & 0.72 & -26.1 & $-26.3 \pm 0.1$ \\
\hline BF 44 & May/02 & 5,800 & 0.89 & -26.1 & $-26.3 \pm 0.1$ \\
\hline BF 73 & May/09 & 6,200 & 1.21 & -25.6 & $-25.7 \pm 0.1$ \\
\hline BF 97 & May/15 & 7,400 & 0.77 & -26.0 & $-26.2 \pm 0.1$ \\
\hline BF 204 & Jun/29 & 8,300 & 0.71 & -28.1 & $-28.3 \pm 0.2$ \\
\hline BF 221 & $\mathrm{Jul} / 07$ & 8,000 & 0.83 & -26.6 & $-26.8 \pm 0.1$ \\
\hline BF 244 & $\mathrm{Jul} / 16$ & 9,400 & 0.66 & -26.5 & $-26.7 \pm 0.1$ \\
\hline BF 274 & $\mathrm{Jul} / 26$ & 9,800 & 0.65 & -26.6 & $-26.8 \pm 0.1$ \\
\hline \multicolumn{6}{|c|}{ Sargasso Sea Cruise (1979) } \\
\hline $\mathrm{BF} 01$ & $\mathrm{Jul} / 1 \mathrm{l}$ & 6,600 & 0.43 & -25.5 & $-25.5 \pm 0.1$ \\
\hline BF 02 & $\mathrm{Jul} / 15$ & 6,600 & 0.48 & -25.3 & $-25.3 \pm 0.1$ \\
\hline BF 03 & $\mathrm{Jul} / 20$ & 7,400 & 0.38 & -25.4 & $-25.4 \pm 0.1$ \\
\hline BF 04 & $\mathrm{Jul} / 25$ & 3,800 & 0.45 & -26.4 & $-26.5 \pm 0.1$ \\
\hline \multicolumn{6}{|c|}{ Flux Atlante Cruise (1985) } \\
\hline BF 01 & $\mathrm{Apr} / \mathbf{3 0}$ & 700 & 0.57 & -25.1 & $-25.1 \pm 0.1$ \\
\hline BF 02 & May/06 & 500 & 0.30 & -21.3 & $-20.3 \pm 0.3$ \\
\hline BF 03 & May/09 & 400 & 0.22 & -22.8 & $-21.7 \pm 0.5$ \\
\hline BF 04 & May/13 & 400 & 0.31 & -22.1 & $-21.1 \pm 0.4$ \\
\hline \multirow{2}{*}{\multicolumn{6}{|c|}{ Southern Hemisphere }} \\
\hline & & & & & \\
\hline BF 01 & Jul/07 & 7,900 & 0.13 & -22.4 & $-21.8 \pm 0.3$ \\
\hline BF 02 & $\mathrm{Jul} / 17$ & 10,400 & 0.11 & -21.8 & $-21.1 \pm 0.3$ \\
\hline BF 03 & $\mathrm{Jul} / 28$ & 10,800 & 0.11 & -22.4 & $-21.8 \pm 0.3$ \\
\hline BF 04 & Aug/0S & 12,600 & 0.07 & -22.2 & $-21.4 \pm 0.3$ \\
\hline BF 14 & $\mathrm{Jan} / 26$ & 20,100 & 0.09 & -21.8 & $-21.3 \pm 0.2$ \\
\hline BF 17 & $\mathrm{Feb} / 17$ & 3,900 & 0.14 & -22.4 & $-21.2 \pm 0.3$ \\
\hline \multicolumn{6}{|c|}{ Peru Cruise (198I) } \\
\hline BF 01 & $\mathrm{Mar} / 14$ & 5,200 & 0.19 & -23.0 & $-22.4 \pm 0.2$ \\
\hline BF 02 & $\mathrm{Mar} / 16$ & 3,300 & 0.06 & -23.9 & $-22.6 \pm 0.7$ \\
\hline BF 03 & $\operatorname{Mar} / 20$ & 3,700 & 0.15 & -23.0 & $-22.1 \pm 0.5$ \\
\hline BF 04 & $\mathrm{Mar} / 22$ & 3,600 & 0.15 & -23.0 & $-22.1 \pm 0.5$ \\
\hline BF 05 & $\operatorname{Mar} / 25$ & 3,100 & 0.27 & -20.4 & $-19.0 \pm 0.5$ \\
\hline BF 06 & $\operatorname{Mar} / 29$ & 4,300 & 0.11 & -22.4 & $-21.2 \pm 0.6$ \\
\hline BF 07 & Apr $/ 01$ & 3,800 & 0.13 & -21.3 & $-19.5 \pm 0.8$ \\
\hline BF 08 & Apr/05 & 4,600 & 0.25 & -20.7 & $-19.8 \pm 0.3$ \\
\hline \multicolumn{6}{|c|}{ Amsterdam Island (1982) } \\
\hline CI 01 & $\mathrm{Feb} / 10$ & 11,000 & 0.155 & -22.5 & $-21.6 \pm 0.6$ \\
\hline \multicolumn{6}{|c|}{ New Zealand (1983) } \\
\hline BF 07 & Jun/20 & 4,600 & 0.15 & -22.4 & $-21.2 \pm 0.4$ \\
\hline BF 20 & $\mathrm{Jul} / 10$ & 2,800 & 0.12 & -24.3 & $-23.7 \pm 0.6$ \\
\hline BF 42 & $\mathrm{Jul} / 28$ & 8,300 & 0.12 & -22.8 & $-22.0 \pm 0.2$ \\
\hline BF 49 & Aug/19 & 7,700 & 0.13 & -22.8 & $-22.1 \pm 0.3$ \\
\hline
\end{tabular}

- Mean error for concentration is $10 \% . \delta^{13} C_{\text {corr }}$ is blank corrected only.

Tellus 38B (1986), 3-4 
Table 2. Concentration and isotopic composition of the atmospheric particulate carbon, as a function of particle size for the cascade impactor samples

\begin{tabular}{|c|c|c|c|c|c|c|}
\hline Location & Mid-date & $\operatorname{Vol}\left(\mathrm{m}^{3}\right)$ & Stage $†$ & $\left.C(\mu \mathrm{gC} \mathrm{m})^{-3}\right)^{*}$ & $\delta^{13} C(\%)$ & $\delta^{13} C_{\text {corr }}(\%)^{*}$ \\
\hline \multicolumn{7}{|c|}{ Northern Hemisphere } \\
\hline & & & 1 & 0.07 & -22.8 & $-23.2 \pm 1.1$ \\
\hline & & & 2 & 0.05 & -23.7 & $-21.8 \pm 1.8$ \\
\hline & & & 3 & 0.04 & -21.9 & $-21.8 \pm 0.9$ \\
\hline \multirow[t]{5}{*}{ CI 026} & Apr $/ 25$ & 6,100 & 4 & 0.04 & -24.6 & $-26.6 \pm 2.6$ \\
\hline & & & 5 & 0.05 & -24.4 & $-26.2 \pm 2.4$ \\
\hline & & & BUF & 0.78 & -26.6 & $-26.9 \pm 0.2$ \\
\hline & & & $\left.\begin{array}{l}1 \\
2\end{array}\right\}$ & 0.05 & -19.5 & $-17.4 \pm 0.7$ \\
\hline & & & 3 & 0.08 & -21.5 & $-21.2 \pm 0.5$ \\
\hline \multirow[t]{6}{*}{ CI 043} & May/03 & 5,000 & 4 & 0.20 & -23.8 & $-24.2 \pm 0.4$ \\
\hline & & & 5 & $<0.01$ & n.d. & n.d. \\
\hline & & & BUF & 1.06 & -26.8 & $-27.1 \pm 0.2$ \\
\hline & & & 1 & 0.02 & -18.7 & $-14.7 \pm 4$ \\
\hline & & & 2 & $<0.01$ & n.d. & n.d. \\
\hline & & & 3 & $<0.01$ & n.d. & \\
\hline \multirow[t]{5}{*}{ CI 072} & May/12 & 10,700 & 4 & 0.15 & -30.5 & $-31.7 \pm 0.6$ \\
\hline & & & 5 & 0.08 & -27.2 & $-28.5 \pm 0.9$ \\
\hline & & & BUF & 0.67 & -27.2 & $-27.5 \pm 0.2$ \\
\hline & & & $\left.\begin{array}{l}1 \\
2\end{array}\right\}$ & 0.04 & -22.2 & $-19.1 \pm 1.5$ \\
\hline & & & 3 & $<0.01$ & n.d. & n.d. \\
\hline \multirow[t]{5}{*}{ CI 203} & Jun/29 & 9,200 & 4 & $<0.01$ & n.d. & n.d. \\
\hline & & & 5 & 0.02 & -26.3 & $-27.1 \pm 0.3$ \\
\hline & & & BUF & 0.61 & -27.5 & $-27.6 \pm 0.1$ \\
\hline & & & $\left.\begin{array}{l}1 \\
2\end{array}\right\}$ & 0.02 & -22.9 & $-17.1 \pm 6$ \\
\hline & & & 3 & $<0.01$ & n.d. & n.d. \\
\hline \multirow[t]{6}{*}{ CI 223} & $\mathrm{Jul} / 07$ & 8,800 & 4 & $<0.01$ & n.d. & n.d. \\
\hline & & & 5 & $<0.01$ & n.d. & n.d. \\
\hline & & & BUF & 0.60 & -27.0 & $-27.1 \pm 0.1$ \\
\hline & & & 1 & 0.04 & -23.6 & $-22.7 \pm 0.4$ \\
\hline & & & 2 & 0.04 & -22.5 & $-21.2 \pm 0.5$ \\
\hline & & & 3 & 0.01 & -22.9 & $-20.0 \pm 1.4$ \\
\hline \multirow[t]{3}{*}{ CI 246} & $\mathrm{Jul} / 16$ & 9,700 & 4 & 0.02 & -23.7 & $-22.1 \pm 0.7$ \\
\hline & & & 5 & 0.02 & -24.5 & $-23.6 \pm 0.6$ \\
\hline & & & BUF & 0.72 & -27.0 & $-27.1 \pm 0.1$ \\
\hline \multicolumn{7}{|c|}{ Southern Hemisphere } \\
\hline \multicolumn{7}{|c|}{ Samoa $(1981)$} \\
\hline CI 016 & $\operatorname{Jan} / 26$ & 16,300 & BUF & 0.050 & -24.4 & $-24.0 \pm 0.4$ \\
\hline \multirow[t]{4}{*}{ CI 123} & Feb/17 & 3,300 & BUF & 0.035 & n.d. & n.d. \\
\hline & & & 1 & 0.025 & -23.3 & $-22.4 \pm 0.3$ \\
\hline & & & 2 & 0.030 & -21.8 & $-20.6 \pm 0.4$ \\
\hline & & & 3 & 0.015 & -24.1 & $-23.1 \pm 0.5$ \\
\hline \multirow[t]{3}{*}{ CI 015} & $\mathrm{Jul} / 22$ & 31,200 & 4 & 0.016 & -23.6 & $-22.4 \pm 0.5$ \\
\hline & & & 5 & 0.015 & -24.0 & $-22.8 \pm 0.5$ \\
\hline & & & BUF & 0.040 & -23.3 & $-23.0 \pm 0.2$ \\
\hline \multicolumn{7}{|c|}{ Peru Cruise (198I) } \\
\hline & & & 1 & 0.050 & -24.5 & $-23.3 \pm 0.7$ \\
\hline & & & 2 & 0.045 & -23.7 & $-20.9 \pm 1.9$ \\
\hline & & & 3 & 0.035 & -23.9 & $-20.9 \pm 2.0$ \\
\hline
\end{tabular}

Tellus 38B (1986), 3-4 
Table 2 (continued)

\begin{tabular}{|c|c|c|c|c|c|c|}
\hline Location & Mid-date & $\operatorname{Vol}\left(\mathrm{m}^{3}\right)$ & Stage $†$ & $\left.C(\mu \mathrm{gC} \mathrm{m})^{-3}\right)^{*}$ & $\delta^{13} C(\%)$ & $\delta^{13} C_{\text {corr }}(\%)^{*}$ \\
\hline \multirow[t]{6}{*}{$\mathrm{CI} 01$} & $\operatorname{Mar} / 14$ & 4,500 & 4 & 0.055 & -23.4 & $-20.7 \pm 1.7$ \\
\hline & & & 5 & 0.105 & -24.2 & $-23.3 \pm 0.5$ \\
\hline & & & BUF & 0.040 & -23.3 & $-20.5 \pm 1.8$ \\
\hline & & & 1 & 0.050 & -25.0 & $-24.5 \pm 0.6$ \\
\hline & & & 2 & 0.040 & -24.1 & $-22.2 \pm 1.3$ \\
\hline & & & 3 & 0.030 & -24.8 & $-23.4 \pm 1.5$ \\
\hline \multirow[t]{6}{*}{ CI 02} & Mar/18 & 5,900 & 4 & 0.045 & -24.8 & $-23.8 \pm 1.2$ \\
\hline & & & 5 & 0.065 & -24.6 & $-23.8 \pm 0.6$ \\
\hline & & & BUF & 0.045 & -23.3 & $-21.5 \pm 1.2$ \\
\hline & & & 1 & 0.045 & -24.0 & $-22.2 \pm 1.2$ \\
\hline & & & 2 & 0.035 & -23.5 & $-20.2 \pm 1.8$ \\
\hline & & & 3 & 0.035 & -24 & $-21.7 \pm 1.6$ \\
\hline \multirow[t]{6}{*}{ CI 03} & $\operatorname{Mar} / 25$ & 5,100 & 4 & 0.050 & -23.0 & $-20.2 \pm 1.6$ \\
\hline & & & 5 & 0.060 & -23.2 & $-21.0 \pm 1.2$ \\
\hline & & & BUF & 0.035 & -22.5 & $-18.6 \pm 2.6$ \\
\hline & & & 1 & 0.060 & -21.3 & $-19.3 \pm 0.7$ \\
\hline & & & 2 & 0.030 & -24.0 & $-22.3 \pm 1.0$ \\
\hline & & & 3 & 0.025 & -23.0 & $-19.9 \pm 1.8$ \\
\hline \multirow[t]{3}{*}{$\mathrm{CI} 04$} & $\mathrm{Apr} / 02$ & 9,800 & 4 & 0.020 & -23.3 & $-20.1 \pm 1.9$ \\
\hline & & & 5 & 0.035 & -23.7 & $-22.1 \pm 1.0$ \\
\hline & & & BUF & 0.010 & -22.2 & $-16.7 \pm 4.0$ \\
\hline \multicolumn{7}{|c|}{ Amsterdam Island (1982) } \\
\hline & & & I & 0.040 & -21.2 & $-20.9 \pm 0.5$ \\
\hline & & & 2 & 0.030 & -21.5 & $-19.6 \pm 0.8$ \\
\hline & & & 3 & 0.015 & -22.8 & $-20.2 \pm 1.3$ \\
\hline \multirow[t]{3}{*}{ CI 01} & Feb/10 & 11,000 & 4 & $<0.010$ & n.d. & n.d. \\
\hline & & & 5 & $<0.010$ & n.d. & n.d. \\
\hline & & & BUF & 0.065 & -24.2 & $-23.9 \pm 0.3$ \\
\hline
\end{tabular}

- Mean error for concentration is $10 \%$ for BUF and $20 \%$ for stages. $\delta^{13} \mathrm{C}$ is blank corrected only.

+ According to the manufacturer, equivalent and aerodynamic diameter cutoffs at $50 \%$ collection efficiency for particles with a density of $1 \mathrm{~g} \mathrm{~cm}^{-3}$, for stage 1 to BUF: $(\mu \mathrm{m})>7.2,3.0,1.5,0.96,0.50,<0.50$.

cantly lower than those observed in the northern hemisphere. Similar observations have been reported for elemental carbon by Heintzenberg (1985). The isotopic ratios, too, show an important geographical variability. Samples from the southern hemisphere are enriched in ${ }^{13} \mathrm{C}$ compared to those from the northern hemisphere.

The samples from the northern hemisphere exhibit concentrations ranging from 0.22 to 1.21 $\mu \mathrm{gC} \mathrm{m} \mathrm{m}^{-3}$. The mean value found in our data set $\left(C_{\text {mean }}=0.54 \pm 0.25 \mu \mathrm{gC} \mathrm{m}^{-3}\right)$ is of the same order as that calculated from previous studies $\left(C_{\text {mean }}=0.43 \pm 0.16 \mu \mathrm{gC} \mathrm{\textrm {m } ^ { - 3 }}\right.$ ) (Table 3). The isotopic composition of these aerosol samples is rather uniform $\left(\delta^{13} C_{\text {mean }}=-24.8 \pm 2.4 \%\right)$. As pointed out in the introduction, such a $\delta^{13} \mathrm{C}$ value probably reflects a continental origin. This con- firms the results of previous studies (Hoffman and Duce, 1977; Chesselet et al., 1981), which showed that major quantities of continental material overwhelm the background of marine derived aerosol characterized by more positive ${ }^{13} \mathrm{C} /{ }^{12} \mathrm{C}$ ratios. It must be emphasized that the concentration levels of atmospheric particulate carbon over the ocean are only one order of magnitude lower than those reported over continental source regions (Duce et al., 1983; Cachier et al., 1985). This contrasts with the much more pronounced decrease in concentration for other components of continental origin, such as the lead aerosol or alumino-silicates. The latter components are either emitted directly in particulate form or undergo gas-to-particle conversions very close to the source. Although 
Table 3. Concentration of particulate carbon on aerosols from remote marine areas

\begin{tabular}{|c|c|c|c|c|}
\hline Location & $\begin{array}{l}\text { No. of } \\
\text { samples }\end{array}$ & $\begin{array}{l}\text { Mean } \\
\left(\mu \mathrm{gC} \mathrm{m}^{-3} \mathrm{STP}\right)\end{array}$ & Analytical method & References \\
\hline \multicolumn{5}{|l|}{ Northern Hemisphere } \\
\hline Enewetak atoll & 9 & $0.82 \pm 0.17$ & dry combustion & Chesselet et al. (1981) and this work \\
\hline Northern Atlantic & 7 & $0.76 \pm 0.42$ & solvent extraction & Ketseridis et al. $(1976)^{*}$ \\
\hline West coast of Ireland & 6 & $0.57 \pm 0.29$ & solvent extraction & Eichmann et al. (1979)* \\
\hline California & 7 & $0.49 \pm 0.26$ & solvent extraction & Hidy et al. (1974) \\
\hline Sargasso Sea & 4 & $0.44 \pm 0.04$ & dry combustion & Chesselet et al. (1981) \\
\hline Atlantic & 7 & $0.40 \pm 0.39$ & proton ind. $\times$ emission & Andreae $(1983)^{*} \dagger$ \\
\hline Hawai & 7 & $0.39 \pm 0.03$ & wet oxidation & Hoffman and Duce (1977) \\
\hline Tropical Pacific & 4 & $0.38 \pm 0.19$ & solvent extraction & Barger and Garrett (1976)* \\
\hline Bermuda & 8 & $0.37 \pm 0.23$ & wet oxidation & Hoffman and Duce (1974) \\
\hline Eastern Atlantic & 4 & $0.35 \pm 0.15$ & dry combustion & This work \\
\hline Bermuda & 8 & $0.29 \pm 0.09$ & wet oxidation & Hoffman and Duce (1974) \\
\hline Equatorial Pacific & 4 & $0.21 \pm 0.11$ & proton ind. $x$ emission & Andreae et al. (1984)† \\
\hline \multicolumn{5}{|l|}{ Southern Hemisphere } \\
\hline Tasmania & 6 & $0.53-$ & solvent extraction & Eichmann et al. (1980) \\
\hline Tasmania & 4 & $0.23 \pm 0.07$ & proton ind. $x$ emission & Andreae (1982) $\dagger$ \\
\hline Tropical Atlantic & 3 & $0.23 \pm 0.08$ & proton ind $x$ emission & Andreae $(1983)^{*} \dagger$ \\
\hline Eastern tropical Pacific & 7 & $0.22 \pm 0.14$ & solvent extraction & Barger and Garrett $(1976)^{*}$ \\
\hline Samoa & 9 & $0.22 \pm 0.09$ & wet oxidation & Hoffman and Duce (1977) \\
\hline Peru & 8 & $0.16 \pm 0.07$ & dry oxidation & This work \\
\hline Equatorial Pacific & 8 & $0.15 \pm 0.05$ & proton ind $x$ emission & Andreae et al. (1984) $\dagger$ \\
\hline Amsterdam & 1 & $0.15-$ & dry oxidation & This work \\
\hline New Zealand & 4 & $0.13 \pm 0.015$ & dry oxidation & This work \\
\hline Samoa & 6 & $0.11 \pm 0.03$ & dry oxidation & This work \\
\hline
\end{tabular}

- Excluding high values near the coast or contaminated samples according to the authors.

+ Fine fraction only: $d<1.7 \mu \mathrm{m}$.

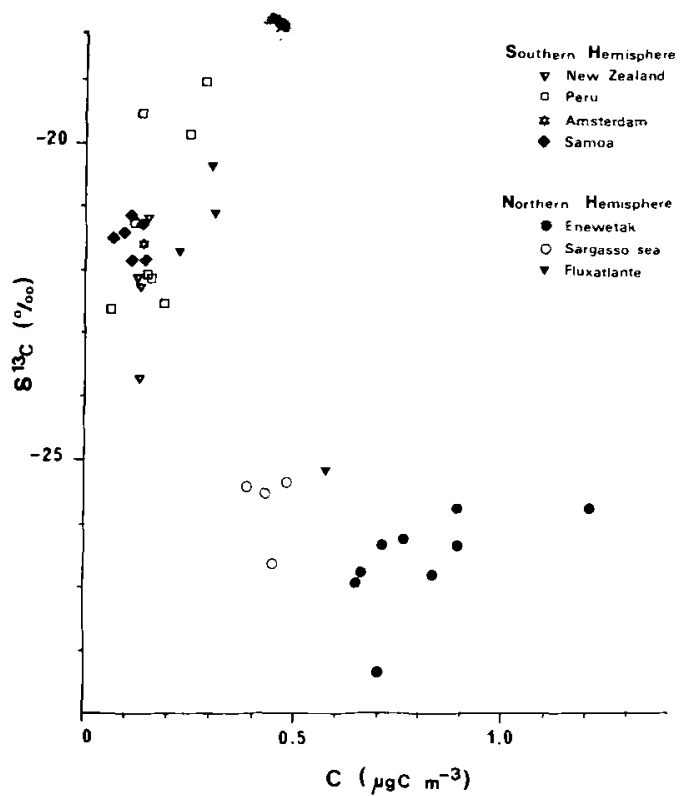

Fig. 2. Particulate carbon isotopic composition as a function of concentration in the marine atmosphere. similar processes are responsible for the carbonaceous aerosol concentrations over the continents, an additional source, probably slow conversion during transport of gaseous species emitted over land, has to be considered to account for our observations. This would explain another feature of our results, i.e., the concentrations observed at the remote site of Enewetak are surprisingly high compared to those observed over the Sargasso Sea closer to the continent and downwind North America. Thus, observed carbon concentration values at Enewetak would imply a higher contribution from the gaseous organic precursors. Such an hypothesis will be substantiated in subsection 3.3. As a whole, in the northern hemisphere, the variability of the particulate carbon concentration should be mostly related to the variability of the continental source strengths, i.e., their marked latitudinal distribution (Andreae, 1983), their seasonal evolution (Cachier et al., 1985; Rosen et al., 1981), and the fluctuations of air-parcel transport (Merrill et al., 1985). 
The samples collected in the southern hemisphere are characterized by low carbon concentrations, which vary little with time and space (0.11 to $0.28 \mu \mathrm{gC} \mathrm{m}^{-3} ; C_{\text {mean }}=0.14 \pm 0.02 \mu \mathrm{gC}$ $\mathrm{m}^{-3}$ ). This suggests that in these remote locations no major continental supply is superimposed on the marine-derived aerosol background. This is in agreement with the distribution of land area and human population between the 2 hemispheres. Furthermore, the isotopic composition of the carbonaceous aerosol is also quite different from that of samples from the northern hemisphere. The $\delta^{13} C$ values are higher and the range is quite large (from -19.0 to $-23.7 \% ; \quad \delta^{13} C_{\text {mean }}=$ $-21.5 \pm 0.5 \%$ ). According to Chesselet et al. (1981), such $\delta^{13} \mathrm{C}$ values could indicate a more important contribution to the atmospheric burden of carbonaceous matter from a marine source.

In the subsection 3.2 we attempt to quantify the relative contributions of marine and nonmarine sources for atmospheric particulate carbon, especially over the southern hemisphere, based on the carbonaceous aerosol concentration and its isotopic composition as a function of particle size (Table 2 and Fig. 3).

\subsection{Source term identification as a function of particle size and carbon isotopic composition}

On the average, as previously mentioned in the Introduction, it seems possible to distinguish between marine and continental source terms over remote oceanic environments. Indeed, it is expected that atmospheric carbonaceous particles of continental origin will be generally found attached to the smallest aerosol particles (Hoffman and Duce, 1977; Chesselet et al., 1981). Therefore, consideration of the distribution patterns of atmospheric concentration as a function of aerosol particle size is obviously the first step required for source identification. However, isotopic data must also support the source term separation. Consequently, this implies a careful consideration of the factors which can influence the observed isotopic variability of the samples. Moreover, such a variability can either be due to the real variability of each type of aerosol source, or reflect a variable mixture of isotopically different continental and marine material.

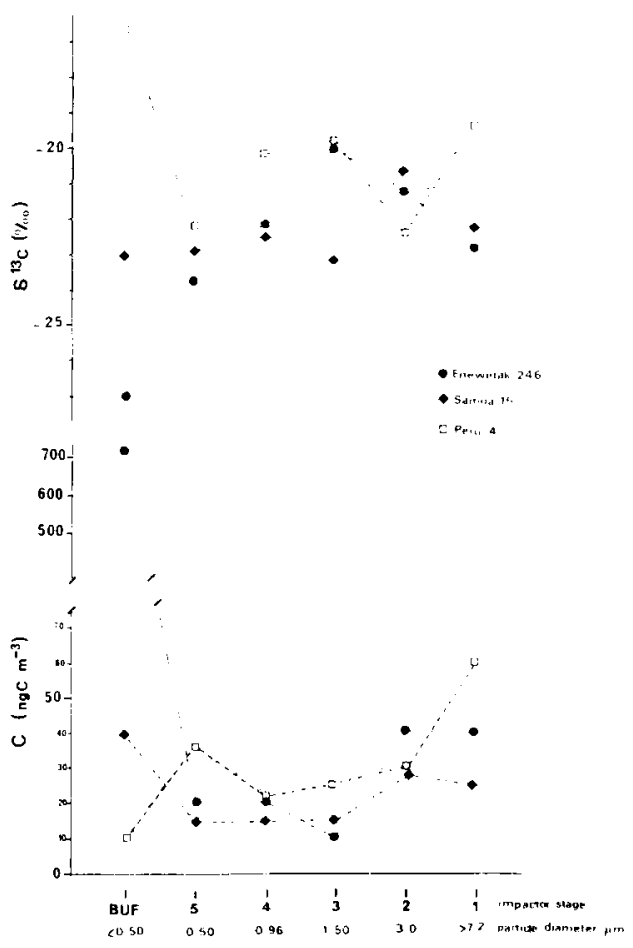

Fig. 3. Examples of variations of carbon concentration and isotopic composition as a function of aerosol particle size in the marine atmosphere.

How the different sources are isotopically characterized, can be summarized as follows.

The marine source of carbonaceous particulate matter has an isotopic composition which is related to that of planktonic matter or its degradation products. The $\delta^{13} \mathrm{C}$ of plankton shows a temperature dependence and, according to Fontugne and Duplessy (1981), its expected average for surface sea-water in temperate and tropical regions is -18 to $-22 \%$. But, in upwelling areas, planktonic tissues display an enrichment in ${ }^{13} \mathrm{C} \quad\left(\delta^{13} \mathrm{C}=-20\right.$ to $\left.-14 \%\right)$, which is also found for suspended organic carbon in surface seawaters of the same regions (Degens et al., 1968; Deuser, 1970; Fontugne, 1983; Descolas-Gros and Fontugne, 1985; this work). These considerations show that the marine source displays primarily a geographical variability in its isotopic composition. Several processes generate carbonaceous aerosols over the continents. The most important are industrial combustion, biomass burning and natural emissions from the 
vegetation. In a study of the tropical aerosol, Cachier et al. (1985) were able to relate the isotopic variability of the fine carbonaceous aerosol emitted $\left(\delta^{13} C\right.$ range: from -19 to $-29 \%$ ), to the different photosynthetic pathways of the plants $\left(C_{3}\right.$ versus $\left.C_{4}\right)$ and the nature of the processes which had generated the particles. Table 4 shows the isotopic values of the fine atmospheric particulate carbon produced over the continents by each active source. The fine aerosols produced by similar sources in other regions are likely to have a similar isotopic signature. Therefore, on a global scale, if no significant isotopic fractionation takes place during transport processes, continentally-derived particulate matter is expected to reflect closely the carbonaceous material emitted over the continents and to display both an areal and a temporal isotopic variability.

From these considerations, it is clear that the $\delta^{13} C$ values of material derived from the ocean and from the continents may overlap. Thus, careful source term identification has to take into account the variability of the isotopic composition of the sources and the size distribution of the aerosol.

3.2.1. Coarse size-fraction of the marine aerosol. The coarse fraction includes particles with diameter $>3 \mu \mathrm{m}$ (stages 1 and 2 of the impactors). Previous $\mathrm{Na}$ measurements (Hoffman and Duce, 1977) and $\delta^{13} C$ measurements (Chesselet et al., 1981) have provided evidence that sea-spray might be responsible for the major part of this size-fraction of the aerosol, and consequently that carbonaceous matter present in this size-range is primarily of marine origin. Indeed, in our set of data, the coarse samples have an isotopic composition which is always in the expected range for marine material at the sampling location $\left(\delta^{13} C=-20 \pm 3 \%\right)$. Therefore, it is possible to assign a marine origin to the coarse fraction of the carbonaceous aerosol over remote marine regions.

However, the Peru cascade impactor samples were collected in non-remote conditions, and their coarse fraction displays a variable isotopic composition. This cannot solely be explained by the variability of the marine source, but rather by a change in the source terms. Impactor 4 has a $\delta^{13} \mathrm{C}$ value closely related to the particular plankton growing in that area (see above) and the marine source can still be assessed as the major source of atmospheric particulate carbon in the coarse size-fraction; but impactors 1,2 and 3 display an isotopic composition $\left(\delta^{13} \mathrm{C}=\right.$ $-23 \pm 1.5 \%$ ) which is not that of the marine organic matter and suggests, therefore, a terrigenous supply during the sampling, possibly due to the vicinity of the coast. A similar conclusion was obtained by Schneider and Gagosian (1985) from the analysis of the lipid material in cascade impactor samples collected at the same time during the same field experiment.

Excluding the Peru samples, atmospheric particulate carbon concentration in the coarsesize fraction appears to vary very little from one location to another. The small fluctuations can be explained by the variable meteorological conditions prevailing during the different

Table 4. Mean isotopic signature and emission rate estimates for some major continental sources of fine atmospheric particulate carbon

\begin{tabular}{|c|c|c|c|}
\hline & \multicolumn{2}{|c|}{$\delta^{13} C(\%)$} & \multirow[b]{2}{*}{ Emission $\left(\times 10^{12} \mathrm{gC} \mathrm{yr}^{-1}\right)$} \\
\hline & mean & range & \\
\hline Industrial combustion" & -25.5 & $(-23 ;-28)$ & 16 \\
\hline Biomass burning $\dagger$ & -26.5 & $(-23 ;-29)$ & 13 \\
\hline Soil erosion $\ddagger$ & -23.0 & $(-22 ;-24)$ & 1 \\
\hline Vegetation§ & -22.5 & $(-12 ;-29)$ & 12 \\
\hline
\end{tabular}

* $\delta^{13} C$ values adapted from Court et al. (1981) and Chesselet et al. (1981). Emission rate from Duce (1978).

$\dagger$ and $\S \delta^{13} \mathrm{C}$ values from Cachier et al. (1985) for tropical regions. These values are supposed to apply also to temperate regions. Emission rates from Cachier et al. (1985).

$\ddagger \delta^{13} \mathrm{C}$ values from Cachier et al. (1985) for tropical regions. Emission rate from Duce (1978). 
sampling times: sea temperature, wind speed, white cap coverage (Duce et al., 1980; Blanchard, 1983) but our results indicate that the marine source of primary carbonaceous aerosol is always weak and rather constant $\left(C_{\text {mean }}=0.07 \mu \mathrm{gC} \mathrm{m}^{-3}\right)$. Even under high productivity conditions, the intensity of this source of atmospheric particulate matter does not seem to be noticeably enhanced.

\subsubsection{Submicrometer size-fraction of the marine} aerosol. The submicrometer size-fraction includes particles collected on the stage 5 and the back up filter (BUF) of the cascade impactor samples. This fraction is likely to include airborne primary aerosol or secondary aerosol produced by gas-toparticle conversion processes. As pointed out by Hoffman and Duce (1977), the marine source of fine primary aerosol is likely to be negligible. Primary aerosol in that size-fraction may thus be primarily continental in origin i.e. soot carbon (Novakov, 1982). On the other hand, the secondary aerosol may, in principle, originate from either a marine or a continental vapor-phase organic carbon pool.

Concentrations of particulate carbon in this size-range are very variable: from a few tenths of $\mathrm{ngC} \mathrm{m^{-3 }}$ up to $1 \mu \mathrm{gC} \mathrm{m}^{-3}$, and their relative contribution to the total particulate carbon concentration appears very important (40 to $95 \%$ ). These results confirm that the fine fraction is the major part of the remote oceanic carbonaceous aerosol. It is then possible to state that the observed variability of the concentration of carbonaceous aerosols in the marine atmosphere is primarily due to the real variability of the fraction attached to submicrometer-sized particles. All the samples from the southern hemisphere exhibit low concentrations of fine atmospheric particulate carbon $(C<100 \mathrm{ngC}$ $\mathrm{m}^{-3}$ ). From this, it could be concluded that the fine particulate carbon found with much higher concentrations in the northern hemisphere is mostly entirely of continental origin.

If correct, this hypothesis has to be supported by considerations of the isotopic composition of the fine carbonaceous aerosol. This fraction, though thought to be mostly continentallyderived, displays a large isotopic variability $\left(\delta^{13} C\right.$ from -17 to $-28 \%$ ). On the basis of either isotopic or concentration data, our cascade impactor samples can be divided into 3 distinct groups (Fig. 3).

The first one includes samples exhibiting high carbon concentrations and an unquestionable continental signature $\left(\delta^{13} \mathrm{C} \leqslant-25 \%\right)$. They were all collected in the northern hemisphere. The particularly negative $\delta^{13} C$ values confirm that these samples contain mostly continental material (Chesselet et al., 1981). Furthermore, based on data given by Cachier et al. (1985), these values could indicate that the material is mostly combustion-derived (Table 4).

The second group includes southern hemisphere samples. They have low concentrations but also display more positive $\delta^{13} C$ values than the previous samples $\left(\delta^{13} C_{\text {mean }}>-24 \%\right)$. The question here is whether their isotopic composition is still compatible with a major continental component for the fine aerosol. Indeed, this shift of the mean isotopic ratio may reflect a change in the mixture of continental source terms towards more natural emissions (Table 4). It could also be due to an increase in the relative importance of the marine contribution to the fine aerosol mixture.

The results obtained for the third group of samples collected in the Peru upwelling area may provide an answer to this question. These samples show an unusual distribution of fine particulate carbon concentration between the 5 th impactor stage (size-range: 0.50 to $0.96 \mu \mathrm{m}$ ) and the BUF (particles smaller than $0.50 \mu \mathrm{m}$ ), the fifth stage being the more loaded. One possible explanation for this observation is that in this region, continental carbon has two distinct origins: a local origin due to the vicinity of the coast (Schneider and Gagosian, 1985), and a more distant source, the particles having undergone long-range transport over the South Pacific. The carbonaceous particles collected on the 5th stage are likely to have primarily a local terrigenous origin from the Peruvian deserts. They show a variable concentration (from 0.04 to $0.11 \mu \mathrm{gC} \mathrm{m}^{-3}$ ) and an isotopic composition which could reflect a predominant contribution of material of continental origin $\left(\delta^{13} C_{\text {mean }}\right.$ $=-22.6 \%$; see Table 4). But, in the same samples, the BUF exhibit particularly low carbon concentrations (from 10 to $40 \mathrm{ngC} \mathrm{m}^{-3}$ ) and more positive $\delta^{13} C$ values $(-17$ to $-20 \%$ ). The latter isotopic compositions are very similar to those 
found in plankton samples collected in surface waters in this region (this work), and attest unambiguously to a marine origin for the particles smaller than $0.5 \mu \mathrm{m}$. These particles could result from gas-to-particle conversion of organic material; though very small, this marine component of the secondary aerosol can appear in the Peru samples due to the favourable combination of 3 factors: the unique isotopic signature of the marine material at that location, the enhanced productivity in upwelling surface waters, and the particularly small load of continental material transported over long distances in the air masses being sampled. Furthermore, isotopic compositions and concentrations of the BUF of impactor samples appear to be approximately linearily related; this could indicate that cascade impactor sample 4 represents the pure marine component of the submicrometer-sized aerosol, characterized by a concentration of $10 \mathrm{ngC} \mathrm{m}$ m $^{-3}$ and a $\delta^{13} \mathrm{C}$ value of $-17 \%$, whereas in the other samples (1 to 3), another component, probably continental (up to $30 \mathrm{ngC} \mathrm{m}^{-3}$ ), is superimposed on this pure marine secondary aerosol background. Since over the open ocean the marine source of fine particulate carbon can be expected to be less active than in upwelling areas, it can be estimated from the above consideration, that the maximum contribution to the submicrometersized aerosol of the tropospheric marine boundary layer from a marine source is of the order of $10 \mathrm{ngC} \mathrm{m}^{-3}$. Therefore, in no case can the variability of the marine source account for the reported variability of the atmospheric particulate carbon concentration over the ocean.
Concentrations of fine atmospheric particulate carbon higher than $20 \mathrm{ngC} \mathrm{m}^{-3}$ should be mostly due to the long-range transport of continentallyderived carbonaceous aerosols. Thus, it is likely that even in the southern hemisphere samples, the particulate carbon present in the fine sizefraction is mostly continental in origin.

In summary, it appears that the geographical location is likely to be the most important determinant of the variability of both the carbonaceous aerosol concentration and its isotopic composition in the remote marine atmosphere. In particular, a strong hemispheric dependence has been reported for the fine-size fraction of the aerosol. Table 5 presents average calculated concentrations and isotopic values for each hemisphere for the marine and the continental components assumed to be mostly attached to the coarse and the fine size-fraction respectively. Our isotopic data provide evidence that the continentally-derived material found in the southern hemisphere samples is certainly different in nature from that found in the northern hemisphere samples. The fractions of intermediate size (diameter between 1 and $3 \mu \mathrm{m}$ ) are likely to result from mixtures of marine and continental source terms. Considering their small importance for the total carbon load of the bulk aerosol, no results are reported for these fractions.

\subsection{Temporal variability of the remote marine carbonaceous aerosol}

In Subsection 3.2, evidence has been presented that the burden of atmospheric particulate

Table 5. Carbonaceous aerosol in tropical and temperate marine atmosphere

\begin{tabular}{|c|c|c|c|c|}
\hline & \multicolumn{2}{|c|}{ Northern Hemisphere } & \multicolumn{2}{|c|}{ Southern Hemisphere } \\
\hline & $\mu \mathrm{gC} \mathrm{m} \mathrm{m}^{-3}$ & $\delta^{13} \mathrm{C} \%$ & $\mu \mathrm{gC} \mathrm{m} \mathrm{m}^{-3}$ & $\delta^{13} C \%$ \\
\hline $\begin{array}{l}\text { Marine material } \\
\text { on large particles } \\
r \geqslant 1.5 \mu \mathrm{m}\end{array}$ & $0.07 \pm 0.02$ & $-21 \pm 2$ & $0.07 \pm 0.02$ & $-21 \pm 2$ \\
\hline $\begin{array}{l}\text { Continental material }+ \\
\text { on small particles } \\
r \leqslant 0.5 \mu \mathrm{m}\end{array}$ & $0.45 \pm 0.25$ & $-25.5 \pm 2$ & $0.06 \pm 0.02$ & $-23.5 \pm 0.5$ \\
\hline
\end{tabular}

\footnotetext{
- Mean values based on the results of cascade impactor samples.

† Mean values based on the results of cascade impactor samples and bulk filter samples (the continental material is the difference between the total concentration and the marine component).
} 
carbon over the ocean is dominated by continentally-derived carbonaceous material primarily attached to submicron particles. Therefore, the variability of this aerosol is expected to be directly related to the variability of the continental inputs of fine carbonaceous matter. Such a variability is governed by continental source intensity and transport processes.

Since, at some locations, sampling was performed over several weeks, it is also possible to gain some insight into the temporal variability of the carbonaceous aerosol. Our results (Tables 2 and 3) clearly indicate that, though less marked than the areal variability, there is a detectable temporal variation of both the concentration and the $\delta^{13} \mathrm{C}$ value of the atmospheric particulate carbon at some sampling locations. This temporal variability of the aerosol shows different trends from one site to another, which may give further information on the variability in the long-range transport of carbonaceous aerosol from continental source regions to the remote marine atmosphere. Because of the limited cascade impactor data set, the temporal variability of the aerosol, though due to its fine fraction, will be discussed on the basis of the results of the analyses of the bulk filters. Indeed, such results can be interpreted in terms of the variability of the continental fraction since the marine component has been found quite constant at any given location.

At Enewetak, experiments were conducted from April to August 1979. More than $90 \%$ of the particulate carbon has been found to be of continental origin and attached to the fine particles. The observed concentration range is 0.65 to 1.2 $\mu \mathrm{gC} \mathrm{m}^{-3}$ and the $\delta^{13} \mathrm{C}$ range is -25.7 to $-28.3 \%$. As suggested by the data in Table 4, the carbon is primarily derived from combustion processes (fossil fuel and biomass burning). The aerosol sampled during the spring is slightly enriched in ${ }^{13} \mathrm{C}\left(\delta^{13} C_{\text {mean }}=-26 \%\right)$ compared to the mean values obtained during the summer $\left(\delta^{13} C_{\text {mean }}=-27 \%\right.$ ). This could indicate that during the spring there is a more important relative contribution of natural sources of carbonaceous aerosol (Table 4). This could also be due to the difference in the nature of the material being burnt, $C_{3}$ or $C_{4}$ plants (Cachier et al., 1985). Moreover, different continental source regions are indicated for this period because air mass trajectory analysis shows a drastic change in the origin of air masses which were derived mostly from Asia in the spring and from tropical North America in the summer (Merrill et al., 1985). Such a change in source regions is also supported by results obtained at the same location for stable lead isotopes (Settle and Patterson, 1982), dust mineralogy (Gaudichet and BuatMenard, 1982; Duce et al., 1980) and lipid markers (Gagosian et al., 1982; Gagosian, 1985). During the first part of the sampling period, high concentrations of many continental components were found in the Enewetak aerosol (soil dust, pollution aerosol, lipids, ${ }^{210} \mathrm{~Pb}$ ). After this period, a sharp decrease (from a factor of 4 to a factor of 40 ) in the concentrations of such tracers was observed. This contrasts with the much less pronounced decrease observed for total particulate carbon. As mentioned in section 3.1, these apparently "buffered" variations of the concentration of the carbonaceous part of the aerosol suggest that the continental source function for particulate carbon is not directly related to that of the other continental tracers. As illustrated by Fig. 4, a careful intercomparison of the variation of the concentrations of carbon and ${ }^{210} \mathrm{~Pb}$, another tracer of the submicronic aerosol of continental origin (Turekian et al., 1977; Turekian and Cochran, 1981), allows the following observations to be made.

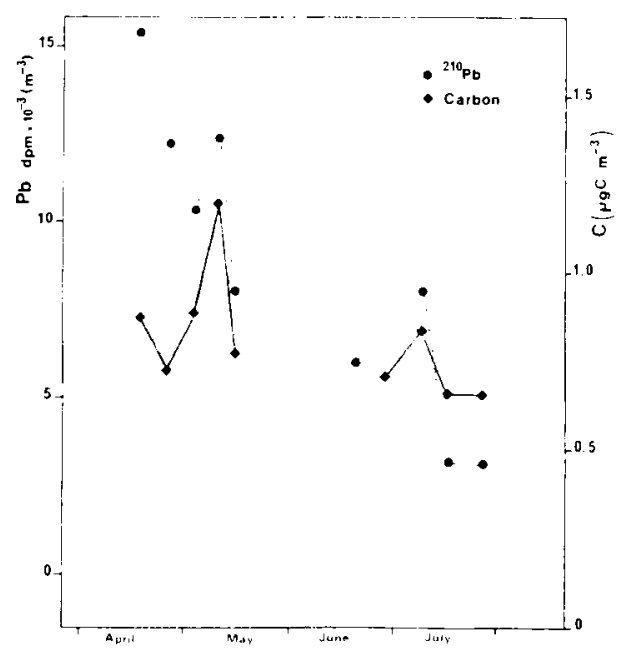

Fig. 4. Temporal variation of particulate carbon and ${ }^{210} \mathrm{~Pb}$ concentrations in atmospheric samples collected at Enewetak Atoll in 1979. $210 \mathrm{~Pb}$ data from Turekian and Cochran (1981). 
(a) The concentrations of these two continental components display a significant covariation, and the covariation is even better in the summer. Atmospheric particulate carbon and ${ }^{210} \mathrm{~Pb}$ are both attached mostly to the submicrometer-sized aerosol; this covariation suggests that these two species experience similar atmospheric pathways and removal processes during their long-range transport over the ocean. ${ }^{210} \mathrm{~Pb}$ is produced in the atmosphere by the decay of the gaseous precursor ${ }^{222} \mathrm{Rn}$ ( 3.8 day half life) emanating from continental soils. Thus, it is likely that an important fraction of the fine carbonaceous aerosol collected at Enewetak originates from gaseous precursors which have a residence time in the atmosphere of the order of a few days. The exact nature and fate of such precursors is at present unknown.

(b) Throughout the whole experiment, there is a continuous shift towards higher values of the $\mathrm{C} /{ }^{210} \mathrm{~Pb}$ concentration ratio (from 60 to $210 \mu \mathrm{gC}$ $\mathrm{dpm}^{-1} 210 \mathrm{~Pb}$ ). As the ${ }^{210} \mathrm{~Pb}$ source function over the continents is quasi-uniform, this could be an indication of the increase of the areal source strength of particulate carbon when the source region shifts from Asia to tropical America. A change in the vegetation cover, in the climatic conditions or in the importance of combustion processes can probably account for such an observation. This indication of the shift of the source regions towards warmer areas has been strongly suggested previously by Gagosian (1985) based on the lipid composition of aerosols (odd to even predominance ratio in the alkanes). It seems therefore that the relative constancy of carbonaceous aerosol concentrations at Enewetak results from the multiplicity of aerosol production processes, source terms and source regions for such material.

At Samoa, investigations during the dry and wet seasons do not show any marked change in the concentration of the bulk aerosol, which remained at a very low level (concentration range: from 0.07 to $0.14 \mu \mathrm{gC} \mathrm{m}^{-3}$ ). The bulk $\delta^{13} C$ value was also remarkably constant $(-21.1$ to $-21.8 \%$ ). The uniformity of the data at this location reflects an almost steady long-range transport of well-mixed continental material. As indicated by the cascade impactor data, the main source of fine carbonaceous aerosol $\left(\delta^{13} C_{\text {mean }}=\right.$ $-23 \%$ ) throughout the year is certainly derived from natural emissions in the tropical regions (Table 4).

During the New Zealand experiments, concentrations of the bulk atmospheric particulate carbon remain constant and at a low level (range from 0.12 to $0.15 \mu \mathrm{gC} \mathrm{m}^{-3}$ ) but more information is provided by the isotopic analyses. Indeed, the isotopic composition of the bulk carbonaceous aerosol is variable (from -21.2 to $-23.7 \%$ ), suggesting temporal changes in the mixture of continental source terms. The existence of such changes is supported by data on lipids, stable lead isotopes and air mass trajectory analysis (Peltzer et al., 1985; Settle and Patterson, 1985) which indicate that during some periods of the experiment, the air being sampled was carrying aerosol particles originating from New Zealand, Tasmania or the Australian continent.

\subsection{Data validation through isotopic constraint}

From the discussion of our data, it seems clear that the burden of fine carbonaceous particles in the marine atmosphere is dominated by the longrange transport of material originating from the continents. Based on the work of Cachier et al. (1985) it is also possible to assess the location, the intensity and the mean isotopic signature of the main sources of fine carbonaceous aerosols over the continents. An attempt is presented to use such information to estimate the relative contribution of the different continental source terms to the fine carbonaceous aerosol burden of the tropospheric marine boundary layer. Four sources dominate over land: industrial combustion, biomass burning, natural emissions from the vegetation and soil erosion by wind. The different source strength estimates, along with their mean isotopic composition, are reported in Table 4. For submicrometer-sized particles, the global emission rate over the continents is

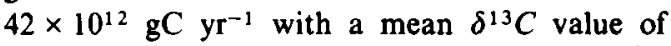
$-24.9 \pm 0.5 \%$. It should be pointed out that the estimates of Duce (1978) for the industrial emissions are derived from data for the years 1972-73. These estimates are likely to be lower than those to be expected 6-10 years later, and consequently the importance of this source may be underestimated here. This would shift slightly the mean isotopic composition of the average continental aerosol towards more negative values $\left(\delta^{13} C\right.$ would be smaller than $-25.0 \%$ ). 
Atmospheric deposition of particulate carbon to the open ocean $(F)$ can be roughly calculated from mean aerosol concentration data $(C)$ and an estimate of the total deposition velocity of the submicronic aerosol $(V)$, which integrates both wet and dry removal processes, using the following equation:

$F\left(\mathrm{gC} \mathrm{m}^{-2} \mathrm{yr}^{-1}\right)=V\left(\mathrm{~m} \mathrm{yr}^{-1}\right) \times C\left(\mathrm{gC} \mathrm{m}^{-3}\right)$.

No value is directly available for carbonaceous aerosol deposition velocity. Nevertheless, it can be estimated that other continentally-derived aerosols, attached to the submicrometer-sized fraction, are removed from the atmosphere with the same efficiency (Slinn, 1983; Zafiriou et al., 1985). We have therefore adopted for $V$ the values obtained for ${ }^{210} \mathrm{~Pb}$ over the ocean by Turekian and Cochran (1981). The total deposition velocity has been found to be in the range of $0.25-4 \mathrm{~cm} \mathrm{~s}^{-1}$ with a mean value of $1.0 \pm 0.5 \mathrm{~cm} \mathrm{~s}^{-1}$. Based on this estimate of $V$, the average fallout rate of fine atmospheric particulate carbon over the ocean is $0.142 \mathrm{gC} \mathrm{m}^{-2}$ $\mathrm{yr}^{-1}$ in the northern hemisphere, and $0.019 \mathrm{gC}$ $\mathrm{m}^{-2} \mathrm{yr}^{-1}$ in the southern hemisphere. On an annual basis, our data indicate that $26 \times 10^{12} \mathrm{~g}$ of fine particulate carbon of continental origin would be deposited over the ocean from the atmosphere. This carbonaceous material would have a calculated mean $\delta^{13} C$ value of $-25.2 \pm 0.5 \%$.

The above calculations indicate that the net annual input to the open ocean of fine atmospheric particulate carbon is only slightly lower than the emission rates over land. Based on estimates of rainfall over the ocean and the mean particulate carbon concentration in the rain, Duce (unpublished data) reached the same conclusion. This result corroborates the hypothesis of an additional source of carbonaceous secondary aerosol produced by the slow gas-to-particle transformations of continental components during its transport in air masses (Duce, 1978; Jaenicke, 1978). However, there is a good agreement between the $\delta^{13} \mathrm{C}$ values of the emitted and the deposited material. Consequently, despite the lack of isotopic information on the gas-phase precursors, it can be assumed that the isotopic composition of the secondary aerosol originating from the additional source during the atmospheric transport is not significantly differ- ent from that of the aerosol collected in continental source regions.

The above considerations lead us therefore to propose an explanation for the observed difference for the mean carbon isotopic composition of the continental component of the fine aerosol in the marine atmosphere of the northern and the southern hemispheres. The atmospheric particulate carbon of the northern hemisphere would reflect the characteristic $\delta^{13} \mathrm{C}$ depletion of combustion-derived material whereas in the southern hemisphere the aerosol would be dominated by natural emissions from the vegetation or soil erosion (Table 5).

Whether this scenario of the source partitioning is relevant only to our limited data set or is representative on a global scale, obviously requires further investigation. A long-term sampling strategy at various remote marine location, especially in the southern hemisphere is needed, as well as more reliable estimates of continental source strengths in each hemisphere. Moreover, a careful investigation of the nature of the organic gaseous precursors of the aerosol and their transformations, along with further isotopic studies, is required.

\section{Acknowledgements}

We wish to thank the following for their support during the field work: the Mid-Pacific Research Laboratory, University of Hawai, the National Oceanic and Atmospheric Administration, the University of Auckland, the Terres Australes et Antarctiques Françaises (TAAF), the Officers and the Crew of RV Atlantis $I I$ and RV Le Suroit, the SEAREX Operation Group at University of Rhode Island. We also thank B. Ray, A. Gaudry, A. Veron for assistance in sample collection, and A. Vigot for technical assistance. Helpful discussions with S. Calvert, R. A. Duce, J. C. Duplessy, R. B. Gagosian, G. Lambert are gratefully appreciated. This work was supported by CNRS, CEA, IFREMER, the Ministère de l'Environnement and the TAAF in France, and by the National Science Foundation, under grants OCE 77-13071, OCE 77-13072, and OCE 81-11895, through a sub-contract with the University of Rhode Island as part of the SEAREX Program. This is CFR contribution no. 772. 


\section{REFERENCES}

Andreae, M. O. 1982. Marine aerosol chemistry at Cape Grim, Tasmania, and Townsville, Queensland. J. Geophys. Res. 87, 8875-8885.

Andreae, M. O. 1983. Soot carbon and excess fine potassium: long-range transport of combustionderived aerosols. Science 220, 1148-1151.

Andreae, M. O., Andreae, T. W., Ferek, R. J. and Raemdonck, H. 1984. Long-range transport of soot carbon in the marine atmosphere. Sci. Total Environ. $36,73-80$.

Barger, W. R. and Garrett, W. D. 1976. Surface active organic material in air over the Mediterranean and over the eastern equatorial Pacific. J. Geophys. Res. $81,3151-3157$.

Blanchard, D. C. 1983. The production, distribution and bacterial enrichment of the sea-salt aerosol. In: Air-sea exchanges of gases and particles (eds. P. S. Liss and W. G. Slinn). Reidel Press, 407-454.

Buat-Ménard, P. and Duce, R. A. 1985. Metal transfer across the air-sea interface: myths and mysteries. In: Metal cycling in the enviromment (ed. T. C. Hutchison). Wiley, New-York.

Cachier, H., Buat-Ménard, P., Fontugne, $M$. and Chesselet, R. 1983. Sources and fluxes of particulate organic carbon (POC) in the remote marine atmosphere. SEAREX Newsletter 6, 13-15.

Cachier, H., Buat-Ménard, P., Fontugne, M. and Rancher, J. 1985. Source terms and source strengths of the carbonaceous aerosol in the Tropics. J. Atmos. Chem. 3, 469-489.

Chesselet, R., Fontugne, M., Buat-Ménard, P., Ezat, U. and Lambert, C. E. 1981. The origin of particulate organic carbon in the marine atmosphere as indicated by its stable carbon isotopic composition. Geophys. Res. Lett. 8, 345-348.

Court, J. D., Goldsack, R. J., Ferrari, L. M. and Polach, H. A. 1981. The use of carbon isotopes in identifying urban air particulate sources. Clean Air Feb 1981, 6-11.

Daisey, J. M., McCaffrey, R. J. and Gallagher, R. A. 1981. Polycyclic aromatic hydrocarbons and total extractable particulate organic matter in the Arctic aerosol. Atmos. Environ. 15, 1353-1363.

Degens, E. T., Behrendt, M., Gotthardt, B. and Reppmann, E. 1968. Metabolic fractionation of carbon isotopes in marine plankton. II-Data on samples collected off the coasts of Peru and Ecuador. Deep-Sea Res. 15, 1-9.

Descolas-Gros, C. and Fontugne, M. 1985. Carbon fixation in marine phytoplankton: carboxylase activities and stable carbon-isotope ratios; physiological and paleoclimatological aspects. Mar. Biol. 87, $1-6$.

Deuser, W. G. 1970. Isotopic evidence for diminishing supply of available carbon during a diatom bloom in the Black Sea. Nature 225, 1069.

Duce, R. A. 1978. Speculations on the budget of particulate and vapor phase non-methane organic carbon in the global troposphere. Pageoph. 116, 244273.

Duce, R. A., Hoffman, G. L. and Zoller, W. H. 1975. Atmospheric trace metal at remote northern and southern hemisphere sites: pollution or natural? Science 187, 59-61.

Duce, R. A., Unni, C. K., Ray, B. J., Prospero, J. M. and Merrill, J. T. 1980 . Long-range atmospheric transport of soil dust from Asia to the tropical north Pacific: temporal variability. Science 209, 1522-1524.

Duce, R. A., Mohnen, V. A., Zimmerman, P. R., Grosjean, D., Cautreels, W., Chatfield, R., Jaenicke, R., Ogren, J. A., Pellizzari, E. D. and Wallace, G. T. 1983. Organic material in the global troposphere. Rev. Geophys. Space Phys. 21, 921-952.

Eichmann, R., Neuling, P., Ketsiridis, G., Hahn, J., Jaenicke, R. and Junge, C. 1979. N-alkane studies in the troposphere. I-Gas and particulate concentrations in North Atlantic air. Atmos. Environ. 13, 587599.

Eichmann, R., Ketsiridis, G., Schebeske, G., Jaenicke, R., Hahn, J., Warneck, P. and Junge, C. 1980. Nalkane studies in the troposphere. II-Gas and particulate concentrations in Indian Ocean air. Atmos. Environ. 14, 695-703.

Fontugne, M. 1983. Organic carbon stable isotopes in the ocean; application to paleoclimatology. PhD Thesis (in French), Université Paris 11, 227 pp.

Fontugne, M. and Duplessy, J. C. 1981. Organic isotopic fractionation by marine plankton in the temperature range -1 to $31^{\circ} \mathrm{C}$. Oceanol. Acta. 4, 85-90.

Gagosian, R. B. 1986. The air-sea exchange of particulate organic matter: the sources and longrange transport of lipids in aerosols. In: NATO advanced study institute on the role of air/sea exchange in geochemical cycling (eds. P. Buat-Ménard and L. Merlivat). Reidel Press, in press.

Gagosian, R. B., Zafiriou, O. C., Peltzer, E. T. and Alford, J. B. 1982. Lipids in aerosols from the tropical north Pacific: temporal variability. $J$. Geophys. Res. 87(C), 11133-11144.

Gaudichet, A. and Buat-Ménard, P. 1982. Mineralogy and origin of atmospheric particles over the Tropical North Pacific (Enewetak atoll) by analytical transmission electron microscopy (in French). C. R. Acad. Sci. 294, 1241-1246.

Heintzenberg, J. 1985. What can we learn from aerosol measurements at baseline stations? J. Atmos. Chem. 3, 153-169.

Hidy, G. M., Mueller, P. K., Wang, H. H., Karney, J., Twiss, S., Imada, M. and Alcocer, A. 1974. Observations of aerosols over southern California coastal waters. J. Appl. Meteorol. 13, 96-107.

Hoffman, E. J. and Duce, R. A. 1974. The organic carbon content of marine aerosols collected on Bermuda. J. Geophys. Res. 79, 4474-4477. 
Hoffman, E. J. and Duce, R. A. 1977. Organic carbon in marine atmospheric particulate matter: concentration and particle size distribution. Geophys. Res. Lett. 4, 449-452.

Jaenicke, R. 1978. The role of organic material in atmospheric aerosols. Pageoph. 116, 283-292.

Ketseridis, G., Hahn, J., Jaenicke, R. and Junge, C. 1976. The organic constituents of atmospheric particulate matter. Atmos. Environ. 10, 603-610.

Ketseridis, G. and Eichmann, R. 1978. Organic compounds in aerosols samples. Pageoph. 116, 275-282.

Marty, J. C. and Saliot, A. 1982. Aerosols in equatorial Atlantic air: n-alcanes concentrations and distributions as a function of particle size. Nature 298, 144147.

Merrill, J. T., Bleck, R. and Avila, L. 1985. Modeling atmospheric transport to the Marshall Islands. $J$. Geophys. Res. 90, 12927-12936.

Novakov, T. 1982. Soot in the atmosphere. In: Particulate carbon atmospheric life cycle (eds. Wolff and Klimisch). Plenum Press, New-York, 19-41.

Peltzer, E. T., Alford, J. B. and Gagosian, R. B. 1984. Methodology for sampling and analysis of lipids in aerosols from the remote marine atmosphere. Tech. Rep., 84-9, Woods Hole Oceanographic Inst., Woods Hole, MA, 103 pp.

Peltzer, E. T., Gagosian, R. B. and Merrill, J. T. 1985. Naturally occurring organic compounds in aerosol samples collected at Ninety Mile Beach, New Zealand: preliminary results. SEAREX Newsletters $8(1), 1-7$.
Rosen, H., Novakov, T. and Bodhaine, B. A. 1981 . Soot in the Arctic. Atmos. Environ. 15, 1371-1374.

Sackett, W. M. 1964. The depositional history and isotopic organic composition of marine sediments. Mar. Geol. 2, 173-185.

Schneider, J, K. and Gagosian, R. B. 1985. Particle size distributions of lipids in aerosols off the coast of Peru. J. Geophys. Res. 90(C), 7889-7898.

Settle, D. M. and Patterson, C. C. 1982. Magnitudes and sources of precipitation and dry deposition fluxes of industrial and natural leads to the north Pacific at Enewetak. J. Geophys. Res. 87, 8857-8869.

Settle, D. M. and Patterson, C. C. 1985. New Zealand results. SEAREX Newsletters $8(1), 10$.

Simoneit, B. R. T., Chester, R. and Eglinton, G. 1977. Biogenic lipids in particulates from the lower atmosphere over the Eastern Atlantic. Nature 267, 682-685.

Slinn, W. G. 1983. Air-to-sea transfer of particles. In: Air-sea exchanges of gases and particles (eds. P. S. Liss and W. G. Slinn). Reidel Press, 299-405.

Turekian, K. K., Nozaki, Y, and Benninger, L. K. 1977. Geochemistry of atmospheric radon and radon products. Ann. Rev. Earth Planet. Sci. 5, 227-255.

Turekian, K. K. and Cochran, J. K. 1981. ${ }^{210} \mathrm{~Pb}$ in surface air at Enewetak and the Asian dust flux to the Pacific. Nature 292, 522-524. Corrigenda, Nature $294,670$.

Zafiriou, O. C., Gagosian, R. B., Peltzer, E. T. and Alford, J. B. 1985. Air-to-sea fluxes of lipids at Enewetak atoll. J. Geophys. Res. 90(D), 2409-2423. 